\title{
Responses of Foreign GA3 Application on Seedling Growth of Castor Bean (Ricinus communis L.) under Salinity Stress Conditions
}

\author{
Xiurong Jiao ${ }^{1,2,3}$, Wenfang Zhi ${ }^{1,2,3}$, Guijuan Liu ${ }^{1,2}$, Guanglong Zhu ${ }^{1,2,4}$, Gongneng Feng ${ }^{5}$,

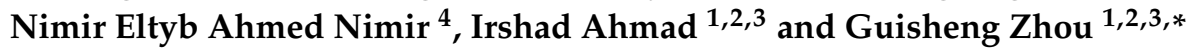 \\ 1 Institutes of Agricultural Science and Technology Development of Yangzhou University, \\ Yangzhou 225009, China; xiurongjiao2016@outlook.com (X.J.); wenfang.zhi@outlook.com (W.Z.); \\ guijuan.liu@outlook.com (G.L.); g.zhu@yzu.edu.cn (G.Z.); Irshadgadoon48@gmail.com (I.A.) \\ 2 Joint International Research Laboratory of Agriculture and Agri-Product Safety, the Ministry of Education \\ of China, Yangzhou University, Yangzhou 225009, China \\ 3 Jiangsu Provincial Key Laboratory of Crop Genetics and Physiology, Yangzhou University, \\ Yangzhou 225009, China \\ 4 Faculty of Agriculture, University of Khartoum, 11115 Khartoum, Sudan; nimir1000@gmail.com \\ 5 Yancheng Institute of Technology, Yancheng 224002, China; ffyalce@ycit.cn \\ * Correspondence: gszhou@yzu.edu.cn; Tel.: +86-133-3885-8866
}

Received: 26 April 2019; Accepted: 25 May 2019; Published: 30 May 2019

\begin{abstract}
Castor bean (Ricinus communis L.), a promising bioenergy crop, is readily planted in marginal lands like saline soils. A controlled experiment was conducted to explore the possibility of using gibberellic acid $\left(\mathrm{GA}_{3}\right)$ as a promoter for caster bean grown under $\mathrm{NaCl}$ conditions and to try to determine the most appropriate concentration of $\mathrm{GA}_{3}$ for seedling growth. The seeds of salt-tolerant cultivar Zibi 5 were firstly soaked with $0,200,250$, and $300 \mu \mathrm{M} \mathrm{GA}_{3}$ for $12 \mathrm{~h}$ and then cultured with $1 / 2$ Hoagland solution containing 0,50 , and $100 \mathrm{mM} \mathrm{NaCl}$ in pots filled with sand. Plant height, stem diameter, leaf area, dry mater of each organ, activity of superoxide dismutase (SOD), peroxidase (POD) and catalase (CAT), soluble protein, and proline content in the leaves were examined. Plant height and stem diameter, SOD, and POD activity was significantly highest in the treatment of $250 \mu \mathrm{M} \mathrm{GA}_{3}$ under salt concentration of $50 \mathrm{mM} \mathrm{NaCl}$ among all the testing days; protein content was highest when $\mathrm{GA}_{3}$ concentration was $250 \mu \mathrm{M}$ under $100 \mathrm{mM} \mathrm{NaCl}$ treatment. This indicated that caster bean seed soaking with $250 \mu \mathrm{M} \mathrm{GA}_{3}$ could be the most suitable concentration for promoting seedling growth of caster bean, improving their stress resistance.
\end{abstract}

Keywords: castor bean; salinity stress; foreign $\mathrm{GA}_{3}$ application; seedling growth and physiological parameters

\section{Introduction}

Castor bean (Ricinus communis L.) is an ideal oilseed crop because of its high seed oil content (more than $\left.480 \mathrm{~g} \mathrm{~kg}^{-1}\right)$, unique fatty acid composition ( $900 \mathrm{~g} \mathrm{~kg}^{-1}$ of ricinoleic acid) [1], and can be successfully mixed with petroleum diesel to reduce air pollution [2]. Due to these characteristics, caster bean has become one of the most promising candidates for biofuel production as well as a vital industrial raw material [3]. In addition, it can tolerate diverse weather conditions, especially, castor bean can be grown under drought and saline conditions [1,4,5]. All these features make it an attractive alternative biodiesel feedstock.

At present, China is rich in saline and alkaline land with 99 million $\mathrm{hm}^{2}$ of saline soil and secondary saline soil and 2.2 million $\mathrm{hm}^{2}$ of coastal mudflat resources [6], but most of them are undeveloped and 
unutilized. One of the economical and efficient ways to improve and develop these saline soils is to screen salt tolerant oil crops [5].

Plants are sensitive to various abiotic stresses at the early stages of growth and development. Caster bean has been found to tolerate moderate salt stress during the later vegetative growth. By empirical observations, castor been seed germination seems not to be sensitive to salt stress [5]. However, it has been suggested that subsequent growth and development of seedlings are severely affected [7]. The threshold of Na salinity for castor emergence and growth is $7.1 \mathrm{dS} \mathrm{m}^{-1}$. At this salinity level, $60 \%$ of the seedlings did not survive when subjected to the threshold salinity level [8].

Salinization has been an important environmental factor limiting crop growth and yield [9-11]. When plants are subjected to salt stress, reactive oxygen species (ROS) such as superoxide $\left(\mathrm{O}_{2}{ }^{-}\right)$and hydrogen peroxide $\left(\mathrm{H}_{2} \mathrm{O}_{2}\right)$ produce as an initial response from the osmotic stress [12,13]. ROS has a detrimental effect on plants through oxidative damage to lipids, proteins, and nucleic acids [14]. However, plants have evolved a series of antioxidant systems that protect them from these potential cytotoxic effects. In which, one of the most effective of the ROS scavenging system is the antioxidant enzymes such as superoxide dismutase (SOD), peroxidase (POX), catalase (CAT), and ascorbate peroxidase (APX) $[13,14]$. Although there have been many reports on the changes of protective enzyme activities in plants under salt stress, few studies have been carried out on the castor bean seedling under salinity stress.

Proteins synthesis is affected by abiotic stresses, and salt-induced proteins have been identified [15]. Protein accumulated in the plants when grown under saline conditions. This might be because these accumulated proteins provide a storage form of nitrogen which could be reutilized when stress is over [16], and may also play a role in osmotic adjustment [17].

Proline is one of the main osmotic regulatory substances in plants under salt stress [18]. It has two main effects in anti-stress. Firstly, it is an osmotic regulatory substance that is used to maintain the osmotic balance between protoplasm and environment. It can form polymers with some intracellular compounds, similar to hydrophilic colloid, to prevent water loss. Secondly, it can reinforce the integrity of membrane structures.

Exogenous application of plant growth phytohormones has been regarded as an effective way to alleviate negative effects of salinity. Among these, gibberellins have been recorded to be a promoter for plant growth under salinity conditions [19-23] which can relieve seed dormancy, promote plant gene expression, increase the synthesis of hydrolase in plants, repair damaged cell membranes and improve seed vitality. Previous studies have shown that the use of exogenous gibberellic acid $\left(\mathrm{GA}_{3}\right)$ can promote seed germination, improve the salt tolerance of seeds, and alleviate the inhibition of salt on seedling growth [22,24-26]. It has also been concluded that usage of $\mathrm{GA}_{3}$ reduces the harmful effects of salinity and increases resistance to salinity in the mustard plant [27].

The aim of this experiment was to evaluate the effects of salinity stress on caster bean at seedling development stage and try to find out the suitable concentration of $\mathrm{GA}_{3}$ for alleviating the salt stress. We conducted a greenhouse experiment to study the different $\mathrm{GA}_{3}$ concentration applications on plant height, stem diameter, leaf area, and dry matter of each part, then examined the superoxide dismutase (SOD), peroxidase (POD), and catalase (CAT) activity. The soluble protein and proline content were also tested with $\mathrm{GA}_{3}$ amendment under the $\mathrm{NaCl}$ treatment at the initial stages of caster bean growth.

\section{Materials and Methods}

\subsection{Plant Materials}

Zibi 5 is a salt-tolerant castor bean cultivar, which was selected from Zibi 5, Zibi 7, and Zibi 8 based on a previous germination test in this study. Zibi 5 was selected because of its relative lower salt injury rate (which was calculated by germination rate, sprout length, and sprout thickness during the seed germination process) than Zibi 7 and Zibi 8 [28] under $100 \mathrm{mM} \mathrm{NaCl}$. The best concentration and 
time of $\mathrm{GA}_{3}$ under different salt stress were also obtained from this previous study by soaking and culture under different salt concentrations [28].

\subsection{Experimental Design}

A pot experiment was conducted in a growth chamber at Joint International Research Laboratory of Agriculture and Agri-Product Safety of Ministry of Education of China, Yangzhou University, Jiangsu Province. The experiment was arranged in a factorial design with three salinity levels including 0,50 , and $100 \mathrm{mM} \mathrm{NaCl}$; and four $\mathrm{GA}_{3}$ concentrations including $0,200,250$, and $300 \mu \mathrm{M}$. The castor bean cultivar used in this study was ZiBi 5, provided by Zibo Agricultural Research Institute in Shandong Province. There were three salinity levels and four $\mathrm{GA}_{3}$ treatments repeated three times for a total of 36 pots for each time.

Homogeneous and healthy caster been seeds were selected and soaked with $0.1 \% \mathrm{HgCl}_{2}$ solution for $15 \mathrm{~min}$ for disinfection, and then rinsed with purified water three times. Then these castor seeds were soaked with different concentrations of $\mathrm{GA}_{3}$ solution in darkroom for $12 \mathrm{~h}$ with a temperature of $25^{\circ} \mathrm{C}$, then the seeds were re-dried to near their original weight. Then, the seeds were buried in the wet sand containing $1 / 2$ concentration of Hoagland solution for $48 \mathrm{~h}$ for pre-germination. Seeds with similar bud length were selected and planted in a plastic tray $(50 \mathrm{~cm}$ long; $30 \mathrm{~cm}$ width; $5 \mathrm{~cm}$ high) with holes at the bottom. Each pot $(5 \mathrm{~cm}$ in top diameter and $2.5 \mathrm{~cm}$ in bottom diameter) was filled with quartz sand. Three seeds were planted in each pot at $3 \mathrm{~cm}$ seeding depth.

The plastic tray was placed in a solution tank filled with $1 / 2$ concentration of Hoagland solution with different $\mathrm{NaCl}$ concentrations. The plastic tray was then placed in a growth chamber. The temperature in the growth chamber was kept at $30 / 25^{\circ} \mathrm{C}$ day/night $(\mathrm{d} / \mathrm{n})$ and $14 / 10 \mathrm{~h} \mathrm{~d} / \mathrm{n}$ under a PAR of $500 \mathrm{~W} \mathrm{~m}^{-2}$ with a relative humidity setting at $55 \%$. The Hoagland solution was replaced once every five days.

\subsection{Measurements}

Plant materials were sampled on the 10, 20, and 30 days after planting. Ten plants were taken from each repetition and washed with distilled water. The length and width of cotyledon and true leaf, plant height, and stem diameter were measured. The stem diameter was measured $1 \mathrm{~cm}$ above the lateral root position. Roots were cleaned and washed with distilled water, and the plants were separated into roots, stems and leaves. Fresh weight was measured. The samples were divided into two parts. One part was put into an oven at $70^{\circ} \mathrm{C}$ for $72 \mathrm{~h}$ until the plant material reached a constant weight for biomass determination. The other part of samples was stored in a $-80^{\circ} \mathrm{C}$ refrigerator after being frozen with liquid nitrogen for the determination of SOD, POD, CAT, soluble protein and proline content.

To measure enzymes activity, $0.5 \mathrm{~g}$ of fresh leaf of caster bean seedlings was cut into small pieces, quartz sand was added and mixed with $5 \mathrm{~mL} 50 \mathrm{mM} / \mathrm{L}$ phosphate buffer solution $(\mathrm{pH}=7.8)$. The mixture was ground in ice condition, then centrifuged at 15,000 r/min for $20 \mathrm{~min}$ with the temperature of $4{ }^{\circ} \mathrm{C}$. The supernatant was taken and kept at low temperature for further determination of SOD, POD, and CAT activity.

SOD activity was measured by monitoring the inhibition of the photochemical reduction of Nitrotetrazolium blue tetrazolium (NBT) spectrophotometrically at $560 \mathrm{~nm}$ [29]. The reaction mixture contained $50 \mathrm{mM}$ of Na-phosphate buffer (pH 7.8), $750 \mu \mathrm{M}$ of NBT, $130 \mu \mathrm{M}$ of methionine, $100 \mu \mathrm{M}$ of EDTA, $20 \mu \mathrm{M}$ of riboflavin, ultrapure water and $0.1 \mathrm{~mL}$ of enzyme extract. The mixture was left for reaction under the fluorescent lamps (4000 Lux) for $30 \mathrm{~min}$. Two controls $(0.1 \mathrm{~mL} \mathrm{pH}=7.8$ phosphate-buffered saline solution (PBS) was used to replace the enzyme solution) were placed in the dark. The absorbance was recorded at $560 \mathrm{~nm}$. One unit of SOD enzyme activity was defined as the quantity of enzyme that reduced the absorbance reading of samples to $50 \%$ in comparison with tubes lacking enzymes.

The activity of POD was determined according to the method of Raza et al. [30]. A total of $0.1 \mathrm{~mL}$ of enzyme solution was added to the reaction solution $\left(0.3 \% \mathrm{H}_{2} \mathrm{O}_{2} 1.95 \mathrm{~mL}, 0.2 \%\right.$ guaiacol $0.95 \mathrm{~mL}$, $\mathrm{pH}=7.0 \mathrm{PBS} 1 \mathrm{~mL}$ ). The enzyme solution was added to the reaction solution, with a $\mathrm{pH}=7.8 \mathrm{PBS}$ 
as blank. The optical density (OD) increment of 0.01 per minute was defined as a vitality unit of POD activity.

CAT activity was determined according to the method of Raza et al. [30], estimating the absorbance decreased at $240 \mathrm{~nm}$ for $120 \mathrm{~s}$, as a result of $\mathrm{H}_{2} \mathrm{O}_{2}$ consumption. Then, $0.1 \mathrm{~mL}$ of enzyme solution was added to the reaction mixture $\left(0.3 \% \mathrm{H}_{2} \mathrm{O}_{2} 1 \mathrm{~mL}\right.$, and $1.9 \mathrm{~mL}$ ultra-pure water). $\mathrm{PBS}$ ( $\mathrm{pH}=7.8$ ) was added to the reaction mixture instead of the enzyme solution as blank for zero adjustment, and changes in absorbance of the reaction solution at $240 \mathrm{~nm}$ were read every $20 \mathrm{~s}$. The reduction in OD of 0.01 per minute was defined as a unit of CAT activity.

The content of soluble proline was determined according to the method of Bates et al. [31], and the soluble protein was determined to the method of Coomassie Brilliant Blue G-250 Staining Method [32].

\subsection{Statistical Analysis}

Within a replicate, the average values across all the plants of each variable on a sampling date were calculated for each treatment. The data were then subjected to analysis of variance (ANOVA) using the statistical package DPS 7.05 for Windows (Beijing, China) [33] according to the two-factor randomized design. Treatment mean differences were separated by the least significant difference (LSD, $p=0.05$ ) test if the F-tests were significant.

\section{Results}

\subsection{The $\mathrm{GA}_{3}$ Effects on Caster Bean Seedling Growth under Different $\mathrm{NaCl}$ Treatments}

The effects of $\mathrm{NaCl}, \mathrm{GA}_{3}$ and their interaction on plant height on 10 days (d), $20 \mathrm{~d}$ and $30 \mathrm{~d}$ were significant, as well as stem diameter and leaf area on $20 \mathrm{~d}$ and $30 \mathrm{~d}$ (Table S1).

Plant height under $100 \mathrm{mM} \mathrm{NaCl}$ was significantly lower than that under 0 and $50 \mathrm{mM} \mathrm{NaCl}$, and plant height under $50 \mathrm{mM} \mathrm{NaCl}$ was slightly higher than that under $0 \mathrm{mM} \mathrm{NaCl}$, but the difference was not significant (Table 1). The highest plant height of the seedling was under the $250 \mu \mathrm{M}$ treatment of $\mathrm{GA}_{3}$ under each salinity treatment during the sampling days (Table 1). On 10, 20, and 30 days after sowing, plant height was highest in the treatment with salt concentration of $50 \mathrm{mM} \mathrm{NaCl}$ and $250 \mu \mathrm{M}$ GA3 with 25.33 and $27.74 \mathrm{~cm}$ on $20 \mathrm{~d}$ and $30 \mathrm{~d}$, respectively, and lowest in the treatment with salt concentration of $100 \mathrm{mM} \mathrm{NaCl}$ and $300 \mu \mathrm{M} \mathrm{GA}_{3}$ (14.72, 16.93, and 20.51, respectively) (Table 1). Thus, it seems that the promotion effects of $\mathrm{GA}_{3}$ at $250 \mu \mathrm{M}$ on plant height was much better than other $\mathrm{GA}_{3}$ concentrations under all the salinity treatments.

Table 1. Effects of different levels of exogenous gibberellic acid $\left(\mathrm{GA}_{3}\right)$ on plant height of caster bean seedlings grown under three levels of $\mathrm{NaCl}$ treatment: 0 (control), 50, and $100 \mathrm{mM}$.

\begin{tabular}{|c|c|c|c|c|c|c|c|c|}
\hline & Salinity Level & $\mathrm{GA}_{3}$ & $10 \mathrm{~d}$ & & $20 \mathrm{~d}$ & & $30 \mathrm{~d}$ & \\
\hline \multirow{12}{*}{$\begin{array}{l}\text { Plant Height } \\
(\mathrm{cm})\end{array}$} & \multirow{4}{*}{0} & 0 & $20.94 \pm 0.75$ & abcd & $21.31 \pm 1.28$ & de & $25.72 \pm 1.21$ & bc \\
\hline & & 200 & $21.87 \pm 0.32$ & $a b c$ & $22.42 \pm 0.14$ & cde & $23.99 \pm 0.29$ & $\mathrm{~d}$ \\
\hline & & 250 & $22.43 \pm 0.52$ & $\mathrm{a}$ & $24.67 \pm 0.67$ & $\mathrm{ab}$ & $27.32 \pm 0.59$ & $\mathrm{ab}$ \\
\hline & & 300 & $20.59 \pm 0.83$ & $\mathrm{~cd}$ & $22.8 \pm 0.12$ & $\mathrm{~cd}$ & $23.59 \pm 0.35$ & $\mathrm{~d}$ \\
\hline & \multirow{4}{*}{50} & 0 & $20.8 \pm 0.78$ & bcd & $22.92 \pm 0.31$ & c & $24.26 \pm 0.3$ & $\mathrm{~cd}$ \\
\hline & & 200 & $21.55 \pm 0.68$ & $\mathrm{abc}$ & $22.98 \pm 0.23$ & c & $26.42 \pm 1.24$ & $\mathrm{ab}$ \\
\hline & & 250 & $22.25 \pm 0.38$ & $\mathrm{ab}$ & $25.33 \pm 0.58$ & $\mathrm{a}$ & $27.74 \pm 0.48$ & $\mathrm{a}$ \\
\hline & & 300 & $21.87 \pm 0.43$ & $a b c$ & $23.67 \pm 0.52$ & $\mathrm{bc}$ & $26.59 \pm 0.33$ & $a b$ \\
\hline & \multirow{4}{*}{100} & 0 & $17.39 \pm 0.12$ & e & $18.6 \pm 0.36$ & $\mathrm{f}$ & $22.8 \pm 0.17$ & de \\
\hline & & 200 & $15.25 \pm 0.37$ & $\mathrm{f}$ & $16.55 \pm 0.26$ & $\mathrm{~g}$ & $21.66 \pm 0.53$ & ef \\
\hline & & 250 & $19.89 \pm 0.11$ & $\mathrm{~d}$ & $21.28 \pm 0.15$ & $\mathrm{e}$ & $23.08 \pm 0.11$ & de \\
\hline & & 300 & $14.72 \pm 0.66$ & $\mathrm{~g}$ & $16.93 \pm 0.25$ & $\mathrm{~g}$ & $20.51 \pm 0.66$ & $\mathrm{f}$ \\
\hline
\end{tabular}

Data are presented as mean \pm standard deviation (SE) $(n=3)$. One-way ANOVA was conducted by Fisher's Least Significant Differences post hoc test. Values without letters in common are significantly different at the $p=0.05$ level within each column for plant height. $10 \mathrm{~d}, 20 \mathrm{~d}$, and $30 \mathrm{~d}$ represent 10,20 , and 30 days after seeding. $\operatorname{LSD}_{0.05}=1.605$, 1.499 , and 1.835 for $10 \mathrm{~d}, 20 \mathrm{~d}$ and $30 \mathrm{~d}$, respectively. 
The stem diameter of seedlings was increased at $200 \mu \mathrm{M} \mathrm{GA}_{3}$ and then decreased with $300 \mu \mathrm{M}$ $\mathrm{GA}_{3}$ concentration. Caster been seedlings grown under $50 \mathrm{mM} \mathrm{NaCl}$ treatment with $250 \mu \mathrm{M} \mathrm{GA}$ treatment showed the highest stem diameters $(0.49,0.52$ and $0.57 \mathrm{~cm}$ on $10 \mathrm{~d}, 20 \mathrm{~d}$ and $30 \mathrm{~d}$, respectively) than many other $\mathrm{GA}_{3}$ concentration treatments (Table 2).

Table 2. Effects of different levels of exogenous $\mathrm{GA}_{3}$ on stem diameter of caster bean seedlings grown under three levels of $\mathrm{NaCl}$ treatment: 0 (control), 50, and $100 \mathrm{mM}$.

\begin{tabular}{|c|c|c|c|c|c|c|c|c|}
\hline & Salinity Level & $\mathbf{G A}_{3}$ & $10 \mathrm{~d}$ & & $20 d$ & & $30 \mathrm{~d}$ & \\
\hline \multirow{12}{*}{$\begin{array}{l}\text { Stem diameter } \\
(\mathrm{cm})\end{array}$} & \multirow{4}{*}{0} & 0 & $0.40 \pm 0.02$ & de & $0.43 \pm 0.00$ & $\mathrm{~g}$ & $0.48 \pm 0.00$ & $\mathrm{~d}$ \\
\hline & & 200 & $0.42 \pm 0.02$ & cde & $0.47 \pm 0.01$ & de & $0.48 \pm 0.00$ & $\mathrm{~d}$ \\
\hline & & 250 & $0.42 \pm 0.01$ & cde & $0.43 \pm 0.00$ & $\mathrm{fg}$ & $0.48 \pm 0.01$ & $\mathrm{~d}$ \\
\hline & & 300 & $0.39 \pm 0.02$ & $\mathrm{e}$ & $0.46 \pm 0.01$ & ef & $0.49 \pm 0.01$ & $\mathrm{~cd}$ \\
\hline & \multirow{4}{*}{50} & 0 & $0.47 \pm 0.02$ & $a b c$ & $0.51 \pm 0.01$ & $a b$ & $0.54 \pm 0.01$ & $a b$ \\
\hline & & 200 & $0.48 \pm 0.01$ & $a b$ & $0.51 \pm 0.01$ & $a b$ & $0.56 \pm 0.02$ & $\mathrm{a}$ \\
\hline & & 250 & $0.49 \pm 0.01$ & $\mathrm{a}$ & $0.52 \pm 0.00$ & $\mathrm{a}$ & $0.57 \pm 0.00$ & $\mathrm{a}$ \\
\hline & & 300 & $0.45 \pm 0.01$ & $a b c$ & $0.49 \pm 0.01$ & bcd & $0.52 \pm 0.01$ & $\mathrm{bc}$ \\
\hline & \multirow{4}{*}{100} & 0 & $0.40 \pm 0.03$ & de & $0.45 \pm 0.01$ & efg & $0.49 \pm 0.02$ & $\mathrm{~cd}$ \\
\hline & & 200 & $0.44 \pm 0.02$ & abcd & $0.48 \pm 0.01$ & $\mathrm{~cd}$ & $0.51 \pm 0.01$ & bcd \\
\hline & & 250 & $0.44 \pm 0.01$ & abcd & $0.51 \pm 0.01$ & $a b$ & $0.57 \pm 0.00$ & $\mathrm{a}$ \\
\hline & & 300 & $0.44 \pm 0.01$ & bcd & $0.50 \pm 0.01$ & bc & $0.54 \pm 0.02$ & $a b$ \\
\hline
\end{tabular}

Data are presented as mean \pm SE $(n=3)$. One-way ANOVA was conducted by Fisher's Least Significant Differences post hoc test. Values without letters in common are significantly different at the $p=0.05$ level within each column for stem diameter. $10 \mathrm{~d}, 20 \mathrm{~d}$, and $30 \mathrm{~d}$ represent 10,20 , and 30 days after seeding. $\mathrm{LSD}_{0.05}=0.050,0.025$, and 0.034 for $10 \mathrm{~d}, 20 \mathrm{~d}$ and $30 \mathrm{~d}$, respectively.

$\mathrm{NaCl}$ treatment significantly decreased leaf area (Table 3). The largest leaf area of caster bean seedling was found with the treatment of salinity concentration of $50 \mathrm{mM}$ and $\mathrm{GA}_{3}$ concentration of $250 \mu \mathrm{M}$ on $20 \mathrm{~d}$ with a value of $43.92 \mathrm{~cm}^{2}$ and with the treatment of salinity concentration of $0 \mathrm{mM}$ and $\mathrm{GA}_{3}$ concentration of $250 \mu \mathrm{M}$ on $30 \mathrm{~d}$ with a value of $88.94 \mathrm{~cm}^{2}$. The leaf area was the smallest when treated with salt concentration of $100 \mathrm{mM} \mathrm{NaCl}$ and $\mathrm{GA}_{3}$ at $300 \mu \mathrm{M}$ on $20 \mathrm{~d}$ and $30 \mathrm{~d}$ (Table 3).

Table 3. Effects of different levels of exogenous $\mathrm{GA}_{3}$ on leaf area of caster bean seedlings grown under three levels of $\mathrm{NaCl}$ treatment: 0 (control), 50, and $100 \mathrm{mM}$.

\begin{tabular}{|c|c|c|c|c|c|c|c|c|}
\hline & Salinity Level & $\mathrm{GA}_{3}$ & $10 \mathrm{~d}$ & & $20 \mathrm{~d}$ & & $30 \mathrm{~d}$ & \\
\hline \multirow{12}{*}{ Leaf area $\left(\mathrm{cm}^{2}\right)$} & \multirow{4}{*}{0} & 0 & $26.19 \pm 2.83$ & $a b$ & $28.47 \pm 1.94$ & $\mathrm{~cd}$ & $84.66 \pm 2.89$ & a \\
\hline & & 200 & $26.94 \pm 4.12$ & $\mathrm{ab}$ & $32.18 \pm 0.49$ & $\mathrm{bc}$ & $48.93 \pm 1.13$ & c \\
\hline & & 250 & $24.66 \pm 2.41$ & $a b c$ & $36.12 \pm 0.82$ & $\mathrm{~b}$ & $88.94 \pm 2.77$ & a \\
\hline & & 300 & $20.46 \pm 2.22$ & bcde & $32.59 \pm 4.29$ & $\mathrm{bc}$ & $63.41 \pm 3.35$ & $b$ \\
\hline & \multirow{4}{*}{50} & 0 & $22.71 \pm 2.34$ & abcd & $34.8 \pm 1.84$ & $\mathrm{~b}$ & $49.56 \pm 2.94$ & c \\
\hline & & 200 & $28.57 \pm 4.02$ & $\mathrm{a}$ & $37.18 \pm 2.92$ & $\mathrm{~b}$ & $53.66 \pm 0.98$ & c \\
\hline & & 250 & $19.57 \pm 0.54$ & bcde & $43.92 \pm 3.06$ & $\mathrm{a}$ & $63.4 \pm 0.91$ & $b$ \\
\hline & & 300 & $22.19 \pm 3.17$ & abcd & $26.54 \pm 2.97$ & $\mathrm{~cd}$ & $41.46 \pm 2.61$ & d \\
\hline & \multirow{4}{*}{100} & 0 & $17.11 \pm 1.84$ & cde & $24.13 \pm 0.57$ & $\mathrm{~d}$ & $31.55 \pm 1.68$ & e \\
\hline & & 200 & $14.33 \pm 0.66$ & $\mathrm{e}$ & $26.62 \pm 0.67$ & $\mathrm{~cd}$ & $40.59 \pm 0.6$ & d \\
\hline & & 250 & $19.55 \pm 2.91$ & bcde & $28.2 \pm 0.88$ & $\mathrm{~cd}$ & $53.68 \pm 1.75$ & c \\
\hline & & 300 & $15.84 \pm 1.46$ & de & $23.65 \pm 0.38$ & $\mathrm{~d}$ & $23.65 \pm 0.38$ & $\mathrm{f}$ \\
\hline
\end{tabular}

Data are presented as mean \pm SE $(n=3)$. One-way ANOVA was conducted by Fisher's Least Significant Differences post hoc test. Values without letters in common are significantly different at the $p=0.05$ level within each column for leaf area. $10 \mathrm{~d}, 20 \mathrm{~d}$, and $30 \mathrm{~d}$ represent 10, 20, and 30 days after seeding. $\operatorname{LSD}_{0.05}=7.636,6.242$, and 6.083 for $10 \mathrm{~d}, 20 \mathrm{~d}$, and $30 \mathrm{~d}$, respectively.

The effects of salt treatment, $\mathrm{GA}_{3}$ concentrations, and their interaction between them on the dry weight of each organ and the whole plant of castor bean seedlings on $10 \mathrm{~d}$ and $20 \mathrm{~d}$ was not significant. 
There was a significant effect of $\mathrm{NaCl}$ on the dry matter of all the plant parts and whole plant on $30 \mathrm{~d}$, while the effect of $\mathrm{GA}_{3}$ on leaf and the whole plant was significant (Table S2). The interaction effect on the dry matter of root was significant on $30 \mathrm{~d}$.

With the increase in salt concentration, the dry weight of leaves, stems, and the whole plant gradually decreased. The difference between 50 and $0 \mathrm{mM} \mathrm{NaCl}$ treatment was not significant, but significantly higher than that of $100 \mathrm{mM} \mathrm{NaCl}$ treatment. With the increase in $\mathrm{GA}_{3}$ concentration, the dry weight of leaves and the whole plant increased first and then decreased, and the dry weight of leaves, stems, roots, and the whole plant treated with $250 \mu \mathrm{M} \mathrm{GA}_{3}$ was the highest. On $30 \mathrm{~d}$ after sowing, seedlings treated with salt concentration of $0 \mathrm{mM} \mathrm{NaCl}$ and $\mathrm{GA}_{3}$ concentration of $250 \mu \mathrm{M}$ had the highest dry weight, while seedlings treated with salt concentration of $100 \mathrm{mM} \mathrm{NaCl}$ and $\mathrm{GA}_{3}$ concentration of $300 \mu \mathrm{M}$ had the lowest dry weight.

\subsection{The GA3 Effects on SOD, POD and CAT under Different $\mathrm{NaCl}$ Treatments}

Significant effects of $\mathrm{NaCl}$ and $\mathrm{GA}_{3}$ and its interactions were found on SOD, POD, CAT, soluble protein, and proline content on all the sampling days (Table S3). $\mathrm{GA}_{3}$ amendment with $250 \mu \mathrm{M}$ significantly increased SOD activity, POD activity, and decreased CAT activity than that of the control treatment on $10 \mathrm{~d}, 20 \mathrm{~d}$, and $30 \mathrm{~d}$ (Table 4).

With the increase in salt concentration, SOD activity increased first and then decreased. In general, SOD with $100 \mathrm{mM} \mathrm{NaCl}$ treatment was significantly lower than $0 \mathrm{mM} \mathrm{NaCl}$ treatment. On $20 \mathrm{~d}$ and $30 \mathrm{~d}$ after sowing, there was no significant difference in SOD activity between 0 and $50 \mathrm{mM} \mathrm{NaCl}$ treatments, but SOD activity of treatment with $100 \mathrm{mM} \mathrm{NaCl}$ was significantly lower than that of 0 and $50 \mathrm{mM} \mathrm{NaCl}$ treatments (Table 4). With the increase in GA3 concentration, SOD activity gradually increased and reached the maximum level at $250 \mu \mathrm{M} \mathrm{GA} 3$ treatment, and then decreased at $300 \mu \mathrm{M}$ under 0 and $50 \mathrm{mM} \mathrm{NaCl}$. On $10 \mathrm{~d}, 20 \mathrm{~d}$, and $30 \mathrm{~d}$ after sowing, SOD activity was highest in the treatment with salt concentration of $0 \mathrm{mM} \mathrm{NaCl}$ and $\mathrm{GA}_{3}$ concentration of $250 \mu \mathrm{M}$ of 1509, 573, and $519 \mathrm{U} / \mathrm{g}$ FW respectively, and lowest in the treatment with salt concentration of $100 \mathrm{mM} \mathrm{NaCl}$ and $\mathrm{GA}_{3}$ concentration of $300 \mu \mathrm{M}$ of 776,405 , and $274 \mathrm{U} / \mathrm{g}$ FW respectively.

With the increase in salt concentration, POD activity first increased at $50 \mathrm{mM} \mathrm{NaCl}$ and then decreased at $100 \mathrm{mM} \mathrm{NaCl}$, and the amount of $100 \mathrm{mM} \mathrm{NaCl}$ was significantly lower than $0 \mathrm{mM} \mathrm{NaCl}$ (Table 4). The POD activity of $\mathrm{GA}_{3}$ treatment was higher than that of the control. Under the conditions of 0 and $50 \mathrm{mM} \mathrm{NaCl}$, POD activity gradually increased with the increase of $\mathrm{GA}_{3}$ concentration to $250 \mu \mathrm{M}$, reaching the maximum, and then decreased slightly. POD activity was the highest in the treatment with a salt concentration of $0 \mathrm{mM}$ and a GA 3 concentration of $250 \mu \mathrm{M}(1995,2648$, and $3187 \mathrm{U} /(\mathrm{g} \cdot \mathrm{min})$ on $10 \mathrm{~d}, 20 \mathrm{~d}$, and $30 \mathrm{~d}$, respectively), and the lowest in the treatment with a salt concentration of $100 \mathrm{mM}$ and a GA 3 concentration of $200 \mu \mathrm{M}(1055,1107$, and $1719 \mathrm{U} /(\mathrm{g} \cdot \mathrm{min})$ on $10 \mathrm{~d}$, $20 \mathrm{~d}$, and $30 \mathrm{~d}$, respectively) (Table 4).

No significant difference in CAT activity was found between the three $\mathrm{NaCl}$ concentrations, while 250 and $300 \mu \mathrm{M} \mathrm{GA}_{3}$ treatment significantly lowered CAT activity than that of the control group under $0 \mathrm{mM}$ and $50 \mathrm{mM} \mathrm{NaCl}$ conditions (Table 4). At 10, 20, and $30 \mathrm{~d}$ after sowing, CAT activity was highest in the treatment with $100 \mathrm{mM} \mathrm{NaCl}$ and $300 \mu \mathrm{M} \mathrm{GA}_{3}$, and lowest in the treatment with $50 \mathrm{mM}$ salt and $250 \mu \mathrm{M} \mathrm{GA}_{3}$. 
Table 4. Effects of different level of exogenous $\mathrm{GA}_{3}$ on superoxide dismutase (SOD), peroxidase (POD), and catalase (CAT) of caster bean seedlings grown under three levels of $\mathrm{NaCl}$ treatment: 0 (control), 50, and $100 \mathrm{mM}$.

\begin{tabular}{|c|c|c|c|c|c|c|c|c|}
\hline & Salinity Level & GA3 & $10 \mathrm{~d}$ & & $20 \mathrm{~d}$ & & $30 \mathrm{~d}$ & \\
\hline \multirow{12}{*}{ SOD (U/g FW) } & \multirow{4}{*}{0} & 0 & $945 \pm 22$ & ef & $540 \pm 23$ & $\mathrm{~cd}$ & $432 \pm 19$ & $\mathrm{c}$ \\
\hline & & 200 & $1031 \pm 21$ & de & $564 \pm 28$ & bcd & $484 \pm 15$ & $\mathrm{bc}$ \\
\hline & & 250 & $1509 \pm 23$ & $\mathrm{a}$ & $662 \pm 23$ & $\mathrm{a}$ & $596 \pm 30$ & $\mathrm{a}$ \\
\hline & & 300 & $1151 \pm 110$ & c & $573 \pm 14$ & bcd & $519 \pm 72$ & $a b c$ \\
\hline & \multirow{4}{*}{50} & 0 & $1024 \pm 28$ & de & $544 \pm 25$ & $\mathrm{~cd}$ & $457 \pm 27$ & $\mathrm{bc}$ \\
\hline & & 200 & $1360 \pm 17$ & $\mathrm{~b}$ & $650 \pm 38$ & $\mathrm{a}$ & $582 \pm 7$ & $\mathrm{a}$ \\
\hline & & 250 & $1340 \pm 23$ & $\mathrm{~b}$ & $602 \pm 34$ & $a b c$ & $543 \pm 11$ & $a b$ \\
\hline & & 300 & $1356 \pm 17$ & $\mathrm{~b}$ & $620 \pm 20$ & $\mathrm{ab}$ & $550 \pm 13$ & $a b$ \\
\hline & \multirow{4}{*}{100} & 0 & $836 \pm 3$ & $\mathrm{fg}$ & $506 \pm 35$ & d & $312 \pm 45$ & $\mathrm{~d}$ \\
\hline & & 200 & $800 \pm 31$ & $\mathrm{~g}$ & $414 \pm 30$ & $\mathrm{e}$ & $285 \pm 44$ & $\mathrm{~d}$ \\
\hline & & 250 & $1079 \pm 53$ & $\mathrm{~cd}$ & $534 \pm 8$ & $\mathrm{~cd}$ & $509 \pm 23$ & $a b c$ \\
\hline & & 300 & $776 \pm 16$ & $\mathrm{~g}$ & $405 \pm 10$ & $\mathrm{e}$ & $274 \pm 2$ & $\mathrm{~d}$ \\
\hline \multirow{12}{*}{$\mathrm{POD}(\mathrm{U} /(\mathrm{g} \cdot \mathrm{min}))$} & \multirow{4}{*}{0} & 0 & $1360 \pm 17$ & $\mathrm{~g}$ & $1411 \pm 21$ & ef & $2032 \pm 26$ & ef \\
\hline & & 200 & $1515 \pm 11$ & $\mathrm{~cd}$ & $1618 \pm 112$ & $\mathrm{~d}$ & $2247 \pm 206$ & de \\
\hline & & 250 & $1995 \pm 54$ & $\mathrm{a}$ & $2648 \pm 80$ & a & $3187 \pm 24$ & $\mathrm{a}$ \\
\hline & & 300 & $1716 \pm 26$ & $\mathrm{bc}$ & $2350 \pm 81$ & $b$ & $2659 \pm 99$ & $\mathrm{~b}$ \\
\hline & \multirow{4}{*}{50} & 0 & $1532 \pm 8$ & $\mathrm{~d}$ & $2010 \pm 16$ & c & $2319 \pm 40$ & $\mathrm{~cd}$ \\
\hline & & 200 & $1750 \pm 6$ & $\mathrm{~b}$ & $2426 \pm 20$ & $b$ & $2648 \pm 48$ & $\mathrm{~b}$ \\
\hline & & 250 & $1968 \pm 13$ & a & $2629 \pm 120$ & a & $3045 \pm 12$ & $\mathrm{a}$ \\
\hline & & 300 & $1631 \pm 8$ & c & $2153 \pm 55$ & c & $2538 \pm 134$ & bc \\
\hline & \multirow{4}{*}{100} & 0 & $1242 \pm 10$ & $\mathrm{~g}$ & $1349 \pm 49$ & ef & $1949 \pm 95$ & $\mathrm{fg}$ \\
\hline & & 200 & $1055 \pm 7$ & $\mathrm{~h}$ & $1107 \pm 58$ & $\mathrm{~g}$ & $1719 \pm 58$ & $\mathrm{~g}$ \\
\hline & & 250 & $1451 \pm 27$ & $\mathrm{f}$ & $1514 \pm 42$ & de & $2119 \pm 57$ & def \\
\hline & & 300 & $1219 \pm 72$ & $\mathrm{~g}$ & $1305 \pm 5$ & $\mathrm{f}$ & $1923 \pm 46$ & $\mathrm{fg}$ \\
\hline \multirow{12}{*}{ CAT $(\mathrm{U} /(\mathrm{g} \cdot \mathrm{min}))$} & \multirow{4}{*}{0} & 0 & $1026 \pm 21$ & $\mathrm{bc}$ & $404 \pm 11$ & $\mathrm{~cd}$ & $384 \pm 5$ & $\mathrm{~d}$ \\
\hline & & 200 & $1041 \pm 16$ & $a b$ & $382 \pm 3$ & $\mathrm{~d}$ & $363 \pm 12$ & de \\
\hline & & 250 & $640 \pm 92$ & $\mathrm{e}$ & $207 \pm 17$ & $\mathrm{f}$ & $183 \pm 6$ & $\mathrm{i}$ \\
\hline & & 300 & $918 \pm 54$ & c & $225 \pm 6$ & $\mathrm{f}$ & $211 \pm 6$ & $\mathrm{~h}$ \\
\hline & \multirow{4}{*}{50} & 0 & $1024 \pm 28$ & $\mathrm{bc}$ & $355 \pm 4$ & de & $345 \pm 8$ & ef \\
\hline & & 200 & $793 \pm 40$ & $\mathrm{~d}$ & $322 \pm 18$ & $\mathrm{e}$ & $309 \pm 2$ & $\mathrm{~g}$ \\
\hline & & 250 & $638 \pm 30$ & $\mathrm{e}$ & $199 \pm 13$ & $\mathrm{f}$ & $173 \pm 3$ & $\mathrm{i}$ \\
\hline & & 300 & $1024 \pm 23$ & bc & $345 \pm 22$ & e & $326 \pm 12$ & $\mathrm{fg}$ \\
\hline & \multirow{4}{*}{100} & 0 & $1081 \pm 6$ & $a b$ & $432 \pm 7$ & c & $413 \pm 5$ & c \\
\hline & & 200 & $1083 \pm 17$ & $a b$ & $484 \pm 6$ & $b$ & $464 \pm 10$ & $b$ \\
\hline & & 250 & $1047 \pm 25$ & $a b$ & $391 \pm 5$ & $\mathrm{~d}$ & $374 \pm 12$ & $\mathrm{~d}$ \\
\hline & & 300 & $1154 \pm 40$ & $\mathrm{a}$ & $532 \pm 19$ & a & $520 \pm 5$ & $\mathrm{a}$ \\
\hline
\end{tabular}

Data are presented as mean \pm SE $(n=3)$. One-way ANOVA was conducted by Fisher's Least Significant Differences post hoc test. Values without letters in common are significantly different at the $p=0.05$ level within each column for SOD, POD, and CAT activity, respectively. $10 \mathrm{~d}, 20 \mathrm{~d}$, and $30 \mathrm{~d}$ represent 10, 20, and 30 days after seeding. $\mathrm{LSD}_{0.05}$ $(\mathrm{SOD})=117.12,75.34$, and 93.02 for $10 \mathrm{~d}, 20 \mathrm{~d}$, and $30 \mathrm{~d}$, respectively; $\mathrm{LSD}_{0.05}(\mathrm{POD})=86.16,191.12$, and 257.07 for $10 \mathrm{~d}, 20 \mathrm{~d}$, and $30 \mathrm{~d}$, respectively; $\mathrm{LSD}_{0.05}(\mathrm{CAT})=114.45,36.81$, and 25.19 for $10 \mathrm{~d}, 20 \mathrm{~d}$, and $30 \mathrm{~d}$, respectively. $10 \mathrm{~d}$, $20 \mathrm{~d}$, and $30 \mathrm{~d}$ represent 10,20 , and 30 days after seeding.

\subsection{The $\mathrm{GA}_{3}$ Effects on Soluble Protein and Proline Content under Different $\mathrm{NaCl}$ Treatments}

With the increase of salt concentration, the soluble protein and proline content in caster bean seedlings increased significantly on most of the sampling days. With the increase of $\mathrm{GA}_{3}$ concentration, the soluble protein and proline content first increased and then decreased, with $250 \mu \mathrm{M}$ of $\mathrm{GA}_{3}$ treatment being the highest for all the $\mathrm{NaCl}$ concentrations. The soluble protein content was highest of 20.65 and $21.15(\mu \mathrm{g} / \mathrm{g} \mathrm{FW})$ on $20 \mathrm{~d}$ and $30 \mathrm{~d}$ when the salt concentration was $100 \mathrm{mM} \mathrm{NaCl}$ and $\mathrm{GA}_{3}$ concentration of $250 \mu \mathrm{M}$. The lowest soluble protein was found in the treatment with salt concentration of $0 \mathrm{mM} \mathrm{NaCl}$ and $\mathrm{GA}_{3}$ of $0 \mu \mathrm{M}$ (Table 5). For the proline content, treatment with $\mathrm{GA}_{3}$ of $300 \mu \mathrm{M}$ had 
the significantly greater values of 41.56 and $27.92(\mathrm{mg} / \mathrm{g} \mathrm{FW})$ under $100 \mathrm{mM} \mathrm{NaCl}$ treatment on $20 \mathrm{~d}$ and $30 \mathrm{~d}$, respectively (Table 5).

Table 5. Effects of different levels of exogenous $\mathrm{GA}_{3}$ on soluble protein and proline content of caster bean seedlings grown under three levels of $\mathrm{NaCl}$ treatment: 0 (control), 50, and $100 \mathrm{mM}$.

\begin{tabular}{|c|c|c|c|c|c|c|c|c|}
\hline & Salinity Level & GA3 & $10 \mathrm{~d}$ & & $20 \mathrm{~d}$ & & $30 \mathrm{~d}$ & \\
\hline \multirow{12}{*}{$\begin{array}{l}\text { Soluble protein } \\
\qquad(\mu \mathrm{g} / \mathrm{g} \text { FW })\end{array}$} & \multirow{4}{*}{0} & 0 & $24.54 \pm 1.3$ & $\mathrm{f}$ & $13.89 \pm 0.59$ & $\mathrm{f}$ & $15.49 \pm 1.02$ & def \\
\hline & & 200 & $25.65 \pm 1.1$ & $\mathrm{f}$ & $14.55 \pm 0.84$ & ef & $14.25 \pm 0.83$ & ef \\
\hline & & 250 & $30.84 \pm 0.43$ & e & $16.14 \pm 0.45$ & def & $16.12 \pm 0.78$ & cde \\
\hline & & 300 & $25.79 \pm 0.96$ & $\mathrm{f}$ & $16.28 \pm 0.9$ & cdef & $15.78 \pm 0.61$ & def \\
\hline & \multirow{4}{*}{50} & 0 & $35.23 \pm 1.17$ & $\mathrm{~cd}$ & $14.89 \pm 0.55$ & def & $17.2 \pm 0.61$ & $\mathrm{~cd}$ \\
\hline & & 200 & $42.74 \pm 0.58$ & $\mathrm{~b}$ & $15.34 \pm 1.48$ & def & $18.34 \pm 0.56$ & $\mathrm{bc}$ \\
\hline & & 250 & $47.64 \pm 1.26$ & $\mathrm{a}$ & $17.34 \pm 1.06$ & bcd & $20.23 \pm 1.83$ & $\mathrm{ab}$ \\
\hline & & 300 & $34.88 \pm 1.51$ & $\mathrm{~cd}$ & $18.74 \pm 0.58$ & $a b c$ & $18.58 \pm 0.51$ & $\mathrm{bc}$ \\
\hline & \multirow{4}{*}{100} & 0 & $32.53 \pm 0.59$ & de & $19.17 \pm 0.22$ & $a b$ & $20.46 \pm 0.61$ & $a b$ \\
\hline & & 200 & $30.18 \pm 2.28$ & $\mathrm{e}$ & $14.17 \pm 1.23$ & $\mathrm{f}$ & $13.49 \pm 0.6$ & $\mathrm{f}$ \\
\hline & & 250 & $37.36 \pm 0.67$ & c & $20.65 \pm 0.68$ & $\mathrm{a}$ & $21.15 \pm 0.81$ & $\mathrm{a}$ \\
\hline & & 300 & $20.12 \pm 0.64$ & $\mathrm{~g}$ & $16.95 \pm 1.07$ & bcde & $13.87 \pm 0.72$ & ef \\
\hline \multirow{12}{*}{$\begin{array}{l}\text { Proline content } \\
\text { (mg/g FW) }\end{array}$} & \multirow{4}{*}{0} & 0 & $15.08 \pm 1.47$ & d & $13.7 \pm 1.9$ & $\mathrm{f}$ & $12.82 \pm 0.63$ & $\mathrm{f}$ \\
\hline & & 200 & $16.75 \pm 1.17$ & d & $11.05 \pm 0.3$ & $\mathrm{f}$ & $13.24 \pm 0.42$ & ef \\
\hline & & 250 & $17.45 \pm 0.74$ & d & $9.37 \pm 0.25$ & $\mathrm{f}$ & $13.03 \pm 0.86$ & $\mathrm{f}$ \\
\hline & & 300 & $15.59 \pm 1.91$ & d & $12.56 \pm 1.28$ & $\mathrm{f}$ & $12.82 \pm 0.63$ & $\mathrm{f}$ \\
\hline & \multirow{4}{*}{50} & 0 & $23.61 \pm 2.49$ & c & $21.7 \pm 2.04$ & $\mathrm{e}$ & $15.7 \pm 1.37$ & def \\
\hline & & 200 & $35.18 \pm 1.02$ & $\mathrm{~b}$ & $24.75 \pm 1.26$ & de & $17.63 \pm 0.99$ & $\mathrm{~cd}$ \\
\hline & & 250 & $37.05 \pm 0.85$ & $\mathrm{~b}$ & $29.79 \pm 1.53$ & $\mathrm{bc}$ & $19.74 \pm 0.33$ & $\mathrm{c}$ \\
\hline & & 300 & $31.67 \pm 2.03$ & $\mathrm{~b}$ & $24.09 \pm 2.68$ & de & $16.26 \pm 0.41$ & de \\
\hline & \multirow{4}{*}{100} & 0 & $66.56 \pm 2.82$ & a & $26.32 \pm 1.59$ & $\mathrm{~cd}$ & $20.61 \pm 1.1$ & c \\
\hline & & 200 & $34.71 \pm 2.51$ & $b$ & $33.86 \pm 0.28$ & $\mathrm{~b}$ & $24.26 \pm 2.18$ & $\mathrm{~b}$ \\
\hline & & 250 & $69.92 \pm 3.29$ & $\mathrm{a}$ & $23.9 \pm 1.23$ & de & $19.84 \pm 1.35$ & c \\
\hline & & 300 & $31.48 \pm 1.53$ & $\mathrm{~b}$ & $41.56 \pm 2.11$ & $\mathrm{a}$ & $27.92 \pm 1.35$ & a \\
\hline
\end{tabular}

Data are presented as mean \pm SE $(n=3)$. One-way ANOVA was conducted by Fisher's Least Significant Differences post hoc test. Values without letters in common are significantly different at the $p=0.05$ level within each column for soluble protein and proline content, respectively. $10 \mathrm{~d}, 20 \mathrm{~d}$, and $30 \mathrm{~d}$ represent 10, 20, and 30 days after seeding. $\mathrm{LSD}_{0.05}$ (Soluble protein) $=3.368,2.553$, and 2.511 for $10 \mathrm{~d}, 20 \mathrm{~d}$, and $30 \mathrm{~d}$, respectively; LSD $_{0.05}$ (Proline content) = $5.788,4.558$, and 3.200 for $10 \mathrm{~d}, 20 \mathrm{~d}$, and $30 \mathrm{~d}$, respectively.

\section{Discussion}

Low level salinity ( $50 \mathrm{mM} \mathrm{NaCl}$ ) had relatively small effects on plant height, leaf growth, and dry weight, and even had promoting effects, e.g., stem diameter of the caster bean seedlings was significantly increased than the control on $10 \mathrm{~d}, 20 \mathrm{~d}$, and $30 \mathrm{~d}$ after sowing. However, high-level of salinity $(100 \mathrm{mM} \mathrm{NaCl})$ had significantly negative effects on castor seedling growth, which significantly reduced plant height, stem diameter, dry weight, and leaf area. Similar findings had been described that low concentration of salt $(<0.3 \%)$ had little effect on the growth of caster beans and even had some promotional effect, while a high concentration of salt $(>0.6 \%)$ significantly inhibited the growth of seedlings [8].

Caster bean seed soaked with $250 \mu \mathrm{M} \mathrm{GA}_{3}$ significantly increased plant height, stem diameter, dry weight, and promoted the growth of leaves under all the $\mathrm{NaCl}$ treatments, while seed treated with other $\mathrm{GA}_{3}$ concentration had little effect on seedling growth (Table 1). Previous study shows that gibberellic acid $\left(\mathrm{GA}_{3}\right)$ treatment has alleviated the negative effect of salinity in growth parameters in terms of leaf area, dry weight of grains, and photosynthetic pigments in wheat (Triticum aestivum L.) [34]. $\mathrm{GA}_{3}$ enhanced plant growth and biomass yield of mustard (Brassica juncea L.) significantly [27], and significantly promoted plant length and plant fresh/dry biomass in soybean (Glycine max L.) while markedly hindered by $\mathrm{NaCl}$ induced salt stress [35]. Similar evidence was also reported that exogenous 
application of gibberellic acid increased the total height and length of internodes in kenaf (Hibiscus cannabinus L.) plants at a low concentration $(1.25 \mathrm{~mL} / \mathrm{L})$ [19]. It has been suggested that increased plant growth with $\mathrm{GA}_{3}$ application can be related to the role of $\mathrm{GA}_{3}$ in stimulating the cell elongation and division and internodal elongation [36,37], and the role in regulating the level of phytohormones [35].

In the present study, plant height and stem diameter were significant higher when castor plants were treated with $\mathrm{GA}_{3}$ at a concentration of $250 \mu \mathrm{M}$ than the other concentrations of $\mathrm{GA}_{3}$ treatment. Seed treated with $300 \mu \mathrm{M} \mathrm{GA}_{3}$ did not have a much stronger promoting effect on plant growth. This is similar to the results that increased level of gibberellin failed to increase the basal diameter, number of leaves, number of nodes, chlorophyll content, and biomass in all kenaf cultivars [19]. Another study also mentioned that the effect of $150 \mathrm{mg} \mathrm{L}^{-1} \mathrm{GA}_{3}$ was much pronounced in improving grain yield when under salt stress compared with the other two concentrations (100 and $200 \mathrm{mg} \mathrm{L}^{-1}$ ) [38]. This indicated that caster bean seed soaking with $250 \mu \mathrm{M} \mathrm{GA}_{3}$ could be the most suitable concentration for promoting seedling growth of caster bean, improving their stress resistance and effectively alleviating the inhibition of salt stress.

Antioxidant enzymes play an important role in the scavenging of reactive oxygen species under salt stress. It has been demonstrated that activities of antioxidant defense enzymes changed in parallel with the increased $\mathrm{H}_{2} \mathrm{O}_{2}$ and salinity [39]. In the present study, compared with the $0 \mathrm{mM}$ salinity level, the POD and SOD activity of castor bean seedlings at $50 \mathrm{mM}$ salinity level was increased significantly at 10, 20, and $30 \mathrm{~d}$ after sowing (Table 4). This indicates that plant antioxidative mechanisms occurred in caster bean seedling for scavenging ROS under low-level salinity conditions. However, the POD and SOD activity of castor bean seedlings at the $100 \mathrm{mM}$ salinity level were decreased significantly compared with that of 0 and $50 \mathrm{mM} \mathrm{NaCl}$ treatment (Table 4). It suggests that the high-level salinity might generate detrimental effects on the antioxidant system. It has been concluded that a severe salt stress often impairs the antioxidant system and causes oxidative stress [40].

At the $50 \mathrm{mM}$ salinity level, compared with the $0 \mu \mathrm{M} \mathrm{GA}_{3}$ treatment, caster bean seedlings with other level of $\mathrm{GA}_{3}$ treatment significantly increased the activity of POD and SOD, and the POD and SOD activity of castor bean seedlings treated with 200 and $250 \mu \mathrm{M} \mathrm{GA}_{3}$ reached the maximum (Table 4). This increased POD and SOD activity be considered as an improved protection which can be used as indicators of enhanced salt tolerance. Even though the activity of SOD and POD under 200 and $300 \mu \mathrm{M} \mathrm{GA}_{3}$ treatment with $100 \mathrm{mM} \mathrm{NaCl}$ was significantly decreased, the enzyme activity under $250 \mu \mathrm{M} \mathrm{GA}_{3}$ treatment remained at a high level (Table 4). Thus, it is concluded that $\mathrm{GA}_{3}$ treatment with an appropriate concentration can enhance the protective enzyme activity in castor bean seedling leaves. Therefore, it is concluded in the present study that $\mathrm{GA}_{3}$ treatment increased the salt tolerance of castor bean seedlings, partly via improving the antioxidant system.

This study also found that with the increase of salt concentration, the activity of CAT decreased after the increasing trend. The change of CAT activity was inversely related with the change of POD and SOD activity (Table 4). A similar result has been found that CAT activity decreased $61.27 \%$ when treated with a $7 \mathrm{dS} \mathrm{m}^{-1}$ salinity level compared with the control in wheat [41]. This study suggested that SOD and POD probably played a key role in scavenging $\mathrm{O}_{2}$ and $\mathrm{H}_{2} \mathrm{O}_{2}$ at low level salinity, and CAT may play an important role in scavenging high level of $\mathrm{H}_{2} \mathrm{O}_{2}$. In order to improve the salt tolerance of plants, it is crucial to maintain a good balance and coordinated expression of several antioxidant enzymes in plants. It might be more reasonable to take the good balance and coordinated expression among SOD, POD, and CAT as the indicator to judge the salt tolerance of plants.

Proline is an important osmolyte and an indicator of stress, as it can reestablish an osmotic balance under stress conditions including salinity [18]. Soluble protein is closely related to plant stress resistance. It has been found that protein synthesis can be triggered in plants under salt stress [42]. Therefore, the increase of salt stress proteins can be considered as a mechanism of plant self-protection and salt resistance. These proteins may be synthesized de novo in response to salt stress or may be present constitutively at a low concentration and increase when plants are exposed to salt stress [43]. 
In the present study, with the increased salinity, the content of proline and soluble protein increased at 10, 20, and $30 \mathrm{~d}$ after seeding (Table 5). It has been mentioned that salt stress had no significant effect on the concentration of soluble proteins at $50 \mathrm{mM} \mathrm{NaCl}$; however, $100 \mathrm{mM} \mathrm{NaCl}$ treatment induced a significant increase in soluble proteins in the leaves of paper mulberry (Broussonetia papyrifera L.) [39]. Another study showed that salinity stress induced a significant increase in the soluble protein and proline content in root and leaf of two wheat cultivars (Triticum aestivum L.) [34]. Proline content can be used as indicator for evaluating the salt tolerance of Lonicera japonica Thunb [44]. After short treatment, the content of proline in the leaves of treelike Lonicera japonica Thunb. increased dramatically with the increased concentration of $\mathrm{NaCl}$. Proline content was significantly increased in soybean under 50 to $200 \mathrm{mM} \mathrm{NaCl}$ [45]. Thus, it further confirms that caster bean seedlings are sensitive to $\mathrm{NaCl}$ stress due to the significantly increased soluble protein and proline content under both 50 and $100 \mathrm{mM} \mathrm{NaCl}$. It has been suggested that proline showed stronger osmotic regulation ability under salinity stress [44]. Our results also confirmed this.

It has been suggested that a high concentration of proline acts as a soluble solute for inter cellular osmotic adjustment $[46,47]$. This study found that the change of soluble protein content and proline content of the changes is similar under salt stress. At the $50 \mathrm{mM}$ salinity level, with increased $\mathrm{GA}_{3}$ level, the content of soluble protein increased first then decreased; proline content increased with the increase of $\mathrm{GA}_{3}$ concentration under low-salt conditions. The soluble protein content was significantly highest when $\mathrm{GA}_{3}$ concentration was $250 \mu \mathrm{M}$ under $100 \mathrm{mM} \mathrm{NaCl}$ treatment (Table 5). For the proline content, treatment with $\mathrm{GA}_{3}$ of $300 \mu \mathrm{M}$ had the significantly largest values under $100 \mathrm{mM} \mathrm{NaCl}$ treatment on $20 \mathrm{~d}$ and $30 \mathrm{~d}$, indicating that protein and proline could accumulate under salt stress, and $\mathrm{GA}_{3}$ treatment was helpful for its accumulation. It has been concluded that the increase in SOD and POD activity and proline content decreased the adverse effects of salinity stress on studied cultivars of wheat [41].

Glycine betaine was shown to improve salt tolerance in Zea mays L. cv. Giza by protecting chloroplast membrane, preserving photosynthetic pigments, enhancing osmotic adjustment, and turgor maintenance by accumulating organic osmolytes (total amino nitrogen, proline, total soluble protein, and total soluble sugars) [47]. From our results, the application of $\mathrm{GA}_{3}$ under $\mathrm{NaCl}$ treatment might improve salt tolerance of caster bean through accumulating soluble protein and proline in the seedling. Similar studies have found that $\mathrm{GA}_{3}$ treatments activated, in most cases, the production of soluble protein in the different organs of the two wheat cultivars as compared with the corresponding salinized plants [34]. An interactive effect of Ascorbic acid (AsA) with $\mathrm{GA}_{3}$ enhanced protein content and the activity of the antioxidant enzyme in common bean plants under salt stress [48]. It has been concluded that $\mathrm{GA}_{3}$ treatment increased adaptation of two wheat cultivars to salinity by osmoregulation using the organic solutes (saccharides and proteins) [34]. Thus, it was concluded that $\mathrm{GA}_{3}$ treatment has alleviated the drastic effect of salinity in caster bean seedlings via protein and proline accumulation in the leaves.

The increase in soluble protein has a certain role in promoting caster bean seedlings to adapt to the high salt environment. Proline is also a ROS scavenger and a source of nitrogen and carbon required for stress recovery [49]. Furthermore, the interaction between proline and protein can increase the solubility of protein, reduce the precipitation of soluble protein, and enhance the hydration of protein. This has illustrated that the accumulation of proline could help to maintain the integrity and the function of the barley vacuole membrane, thus leading to enhance the ability to resist salt damage [50].

\section{Conclusions}

An appropriate amount of $\mathrm{GA}_{3}$ has been reported in many crops to mitigate the harmful effect of abiotic stress. However, the exact concentration of $\mathrm{GA}_{3}$ to make this alleviation for caster beans has not been studied previously. Our study examined many $\mathrm{GA}_{3}$ concentrations on ameliorating gradual levels of salinity. In our study, plant height and stem diameter, SOD activity and POD activity were significantly highest in the treatment of $250 \mu \mathrm{M} \mathrm{GA}_{3}$ under salt concentration of $50 \mathrm{mM} \mathrm{NaCl}$ among 
all the treatments. The soluble protein content was highest when $\mathrm{GA}_{3}$ concentration was $250 \mu \mathrm{M}$ under $100 \mathrm{mM} \mathrm{NaCl}$ treatment. $\mathrm{GA}_{3}$ alleviated salinity stress on castor seedlings by regulating the activity of antioxidase and accumulating the content of proline and soluble protein. Based on these results, it is concluded that caster bean seed soaking with $250 \mu \mathrm{M} \mathrm{GA}_{3}$ could be the most suitable concentration for promoting seedling growth of caster beans, improving their stress resistance and effectively alleviating the inhibition of salt stress.

Supplementary Materials: The following are available online at http://www.mdpi.com/2073-4395/9/6/274/s1, Table S1: $\mathrm{F}$ values from ANOVA for plant height, stem diameter, leaf area related to $\mathrm{NaCl}, \mathrm{GA}_{3}$ and their interactions of castor bean seedlings, Table S2: $\mathrm{F}$ values from ANOVA for dry matter related to $\mathrm{NaCl}, \mathrm{GA}_{3}$ and their interactions of castor bean seedlings, Table S3: F values from ANOVA for SOD, POD and CAT activity, soluble protein and proline content related to $\mathrm{NaCl}, \mathrm{GA}_{3}$ and their interactions of castor bean seedlings.

Author Contributions: G.Z. (Guisheng Zhou) applied for the funding, administrated the project and designed the study. W.Z and G.L. conducted the experiments. X.J. prepared the data, undertook the analysis and wrote the manuscript. G.Z. (Guanglong Zhu) and G.F., N.E.A.N. and I.A. provided direction and supervised the work. All authors contributed to editing the manuscript.

Funding: This research was funded, in part, by Jiangsu Provincial Key R \& D Program (BE2016345), Jiangsu Provincial Agricultural Innovation Fund (CX16(1005)), and Jiangsu Provincial Modern Agricultural Industrialization Development Program (2019).

Conflicts of Interest: The authors declare no conflict of interest.

\section{References}

1. Severino, L.S.; Auld, D.L.; Baldanzi, M.; Cândido, M.J.D.; Chen, G.; Crosby, W.; Tan, D.; He, X.H.; Lakshmamma, P.; Lavanya, C. A review on the challenges for increased production of castor. Agron. J. 2012, 104, 853. [CrossRef]

2. Berman, P.; Nizri, S.; Wiesman, Z. Castor oil biodiesel and its blends as alternative fuel. Biomass Bioenergy 2011, 35, 2861-2866. [CrossRef]

3. Barnes, D.J.; Baldwin, B.S.; Braasch, D.A. Degradation of ricin in castor seed meal by temperature and chemical treatment. Ind. Crop. Prod. 2009, 29, 509-515. [CrossRef]

4. Rosa, L.M.G.; Sausen, T.L. Growth and limitations to carbon assimilation in Ricinus communis (Euphorbiaceae) under soil water stress conditions. Acta Bot. Bras. 2010, 24, 648-654.

5. Li, G.; Wan, S.; Zhou, J.; Yang, Z.; Qin, P. Leaf chlorophyll fluorescence, hyperspectral reflectance, pigments content, malondialdehyde and proline accumulation responses of castor bean (Ricinus communis L.) seedlings to salt stress levels. Ind. Crop. Prod. 2010, 31, 13-19. [CrossRef]

6. Qadir, M.; Emmanuelle Quillérou, V.; Nangia, G.; Murtaza, M.; Singh, R.J.; Thomas, P.; Drechsel; Noble, A.D. Economics of salt-induced land degradation and restoration. Nat. Resour. Forum. 2014, 38, $282-295$. [CrossRef]

7. Pinheiro, H.A.; Silva, J.V.; Endres, L.; Ferreira, V.M.; Câmara, C.D.A.; Cabral, F.F.; Oliveira, J.F.; Carvalho, L.W.T.D.; Santos, J.M.D.; Filho, B.G.D.S. Leaf gas exchange, chloroplastic pigments and dry matter accumulation in castor bean (Ricinus communis L) seedlings subjected to salt stress conditions. Ind. Crop. Prod. 2008, 27, 385-392. [CrossRef]

8. Zhou, G.S.; Ma, B.L.; Li, J.; Feng, C.N.; Lu, J.F.; Qin, P. Determining salinity threshold level for castor bean emergence and stand establishment. Crop. Sci. 2010, 50, 2030-2036. [CrossRef]

9. Gupta, B.; Huang, B.R. Mechanism of Salinity Tolerance in Plants: Physiological, Biochemical, and Molecular Characterization. Int. J. Genom. 2014, 701596. [CrossRef]

10. Negrao, S.; Schmockel, S.M.; Tester, M. Evaluating physiological responses of plants to salinity stress. Ann. Bot. 2017, 119, 1-11. [CrossRef]

11. Nackley, L.L.; Kim, S.H. A salt on the bioenergy and biological invasions debate: Salinity tolerance of the invasive biomass feedstock Arundo donax. Glob. Chang. Biol. Bioenergy 2015, 7, 752-762. [CrossRef]

12. Hanana, M.; Hamrouni, L.; Cagnac, O.; Blumwald, E. Mechanisms and strategies of cellular tolerance to salinity $(\mathrm{NaCl})$ in plants. Environ. Rev. 2011, 19, 121-140. [CrossRef]

13. Tuteja, N. Mechanisms of high salinity tolerance in plants. Methods Enzymol. 2007, 428, 419-438. [CrossRef] 
14. Acosta-Motos, J.R.; Ortuño, M.F.; Bernal-Vicente, A.; Diaz-Vivancos, P.; Sanchez-Blanco, M.J.; Hernandez, J.A. Plant Responses to Salt Stress: Adaptive Mechanisms. Agronomy 2017, 7, 18. [CrossRef]

15. Sousa, M.F.; Campos, F.A.P.; Prisco, J.T.; Enéas-Filho, J.; Gomes-Filho, E. Growth and Protein Pattern in Cowpea Seedlings Subjected to Salinity. Biol. Plant. 2003, 47, 341-346. [CrossRef]

16. Singh, N.K.; Bracker, C.A.; Hasegawa, P.M.; Handa, A.K.; Buckel, S.; Hermodson, M.A.; Pfankoch, E.; Regnier, F.E.; Bressan, R.A. Characterization of osmotin: A thaumatin-like protein associated with osmotic adaptation in plant cells. Plant Physiol. 1987, 85, 529-536. [CrossRef]

17. Qasim, M.; Ashraf, M.; Ashraf, M.Y.; Rehman, S.U.; Rha, E.S. Salt-Induced Changes in Two Canola Cultivars Differing in Salt Tolerance. Biol. Plant. 2003, 46, 629-632. [CrossRef]

18. Kattab, H. Role of Glutathione and Polyadenylic Acid on the Oxidative Defense Systems of Two Different Cultivars of Canola Seedlings Grown under Saline Condition. Aust. J. Basic Sci. 2007, 1, 323-334.

19. Muniandi, S.K.M.; Hossain, M.A.; Abdullah, M.P.; Shukor, N.A.A. Gibberellic acid (GA3) affects growth and development of some selected kenaf (Hibiscus cannabinus L.) cultivars. Ind. Crops Prod. 2018, 118, 180-187. [CrossRef]

20. Camara, M.C.; Vandenberghe, L.P.S.; Rodrigues, C.; Oliveira, J.D.; Faulds, C.; Bertrand, E.; Soccol, C.R. Current advances in gibberellic acid (GA3) production, patented technologies and potential applications. Planta 2018, 248, 1-14. [CrossRef]

21. Nimir, N.E.A.; Lu, S.; Zhou, G.; Guo, W.; Ma, B.; Wang, Y.; Nimir, N.E.A.; Lu, S.; Zhou, G.; Guo, W. Comparative effects of gibberellic acid, kinetin and salicylic acid on emergence, seedling growth and the antioxidant defence system of sweet sorghum (Sorghum bicolor) under salinity and temperature stresses. Crop Pasture Sci. 2017, 66, 145. [CrossRef]

22. Kandil, A.A.; Sharief, A.E.; Abido, W.A.E.; Awed, A.M. Effect of Gibberellic Acid on Germination Behaviour of Sugar Beet Cultivars under Salt Stress Conditions of Egypt. Sugar Tech 2014, 16, 211-221. [CrossRef]

23. Misratia, K.M.; Ismail, M.R.; Hakim, M.A.; Musa, M.H.; Puteh, A. Effect of salinity and alleviating role of gibberellic acid (GA3) for improving the morphological, physiological and yield traits of rice varieties. Aust. J. Crop Sci. 2013, 7, 1682-1692.

24. Muhammad, J.; Eui Shik, R. Gibberellic acid (GA3) enhance seed water uptake, germination and early seedling growth in sugar beet under salt stress. Pak. J. Biol. Sci. 2007, 10, 654-658.

25. Chunthaburee, S.; Sanitchon, J.; Pattanagul, W.; Theerakulpisut, P. Alleviation of salt stress in seedlings of black glutinous rice by seed priming with spermidine and gibberellic acid. Not. Bot. Horti Agrobot. 2014, 42, 1003-1012. [CrossRef]

26. Nasri, N.; Mahmoudi, H.; Baatour, O.; M'Rah, S.; Kaddour, R.; Lachâal, M. Effect of exogenous gibberellic acid on germination, seedling growth and phosphatase activities in Lettuce under salt stress. Afr. J. Biotechnol. 2012, 11, 11967-11971.

27. Ahmad, P. Growth and antioxidant responses in mustard (Brassica juncea L.) plants subjected to combined effect of gibberellic acid and salinity. Arch. Agron. Soil Sci. 2010, 56, 14. [CrossRef]

28. Jiao, X. (Institutes of Agricultural Science and Technology Development of Yangzhou University, Yangzhou, China); Liu, G. (Institutes of Agricultural Science and Technology Development of Yangzhou University, Yangzhou, China); Zhu, G. (Institutes of Agricultural Science and Technology Development of Yangzhou University, Yangzhou, China); Feng, G. (Yancheng Institute of Technology, Yancheng, China); Zhou, G. (Institutes of Agricultural Science and Technology Development of Yangzhou University, Yangzhou, China). Unpublished data. 2018.

29. Beauchamp, C.; Fridovich, I. Superoxide dismutase: Improved assays and an assay applicable to acrylamide gels. Anal. Biochem. 1971, 44, 276-287. [CrossRef]

30. Raza, S.H.; Athar, H.R.; Ashraf, M.; Hameed, A. Glycinebetaine-induced modulation of antioxidant enzymes activities and ion accumulation in two wheat cultivars differing in salt tolerance. Environ. Exp. Bot. 2007, 60, 368-376. [CrossRef]

31. Bates, L.S.; Waldren, R.P.; Teare, I.D. Rapid determination of free proline for water-stress studies. Plant Soil 1973, 39, 205-207. [CrossRef]

32. Sedmak, J.J.; Grossberg, S.E. A rapid, sensitive, and versatile assay for protein using Coomassie brilliant blue G250. Anal. Biochem. 1977, 79, 544-552. [CrossRef]

33. Tang, Q.Y.; Feng, M.G. Practical Statistics and DPS Data Processing System; China Agriculture Press: Beijing, China, 1997. 
34. Mka, S.; Hm, A.E.S.; Mostafa, D. Role of gibberellic acid (GA3) in improving salt stress tolerance of two wheat cultivars. Int. J. Plant Physiol. Biochem. 2013, 5, 50-57.

35. Hamayun, M.; Khan, S.A.; Khan, A.L. Exogenous Gibberellic Acid Reprograms Soybean to Higher Growth and Salt Stress Tolerance. J. Agric. Food Chem. 2010, 58, 7226. [CrossRef]

36. Taiz, L.; Zeiger, E. Plant Physiology, Fourth Edition; Sinauer Associates: Sunderland, MA, USA, 2006; pp. 510-512.

37. Qian, X.; Burgess, P.; Xu, J.; Meyer, W.; Huang, B. Osmotic stress- and salt stress-inhibition and gibberellin-mitigation of leaf elongation associated with up-regulation of genes controlling cell expansion. Environ. Exp. Bot. 2016, 131, 101-109.

38. Iqbal, M.; Ashraf, M. Gibberellic acid mediated induction of salt tolerance in wheat plants: Growth, ionic partitioning, photosynthesis, yield and hormonal homeostasis. Environ. Exp. Bot. 2013, 86, 76-85. [CrossRef]

39. Min, Z.; Fang, Y.; Ji, Y.; Jiang, Z.; Lei, W. Effects of salt stress on ion content, antioxidant enzymes and protein profile in different tissues of Broussonetia papyrifera. S. Afr. J. Bot. 2013, 85, 1-9.

40. Foyer, C.H.; Noctor, G. Redox sensing and signalling associated with reactive oxygen in chloroplasts, peroxisomes and mitochondria. Physiol. Plant. 2010, 119, 355-364. [CrossRef]

41. Bezabih, M.; Sarr, M. Effects of phytohormones on proline content and antioxidant enzymes of various wheat cultivars under salinity stress. J. Plant Nutr. 2012, 35, 1098-1111.

42. Hong, Z.; Zu, Y.; Wang, W.; Yan, Y. Effect of Proline on Plant Growth under Different Stress Conditions. J. Northeast For. Univ. 2009, 37, 86-89. (In Chinese)

43. Pareek, A.; Singla, S.L.; Grover, A. Salt responsive proteins/genes in crop plants. In Strategies for Improving Salt Tolerance in Higher Plants; Jaiwal, P.K., Singh, R.P., Gulati, A., Eds.; Oxford and IBH Publication Co.: New Delhi, India, 1997; pp. 365-391.

44. Bao, Y.J.; Jing, J.I.; Wang, D. Effects of Salt Stress on the Contents of Proline in Different Varieties of Lonicera japonica Thunb. Med. Plant 2011, 2, 13-14. (In Chinese)

45. Amirjani, M.R. Effect of salinity stress on growth, mineral composition, proline content, antioxidant enzymes of soybean. Am. J. Plant Physiol. 2010, 5, 350-360. [CrossRef]

46. Silveira, J.A.G.; Viégas, R.D.A.; Rocha, I.M.A.D.; Moreira, R.D.A.; Oliveira, J.T.A. Proline accumulation and glutamine synthetase activity are increased by salt-induced proteolysis in cashew leaves. J. Plant. Physiol. 2003, 160, 115-123. [CrossRef]

47. Hassanein, R.A.; Hassanein, A.A.; Haider, A.S.; Hashem, H.A. Improving salt tolerance of Zea mays L. plants by presoaking their grains in glycine betaine. Aust. J. Basic Appl. Sci. 2009, 3, 928-942.

48. Saeidi-Sar, S.; Afshari, H.; Yaghoobi, S.R. Effects of ascorbic acid and gibberellin A on alleviation of salt stress in common bean (Phaseolus vulgaris L.) seedlings. Acta Physiol. Plant. 2013, 35, 667-677. [CrossRef]

49. Khedr, A.H.; Abbas, M.A.; Wahid, A.A.; Quick, W.P.; Abogadallah, G.M. Proline induces the expression of salt-stress-responsive proteins and may improve the adaptation of Pancratium maritimum L. to salt-stress. J. Exp. Bot. 2003, 54, 2553-2562. [CrossRef] [PubMed]

50. Zhao, F.G.; Qin, P. Protective effect of exogenous polyamines on root tonoplast function against salt stress in barley seedlings. Plant Growth Regul. 2004, 42, 97-103. [CrossRef]

(C) 2019 by the authors. Licensee MDPI, Basel, Switzerland. This article is an open access article distributed under the terms and conditions of the Creative Commons Attribution (CC BY) license (http://creativecommons.org/licenses/by/4.0/). 